PTCS が進展範囲診断および術式選択に有用であった 粘液産生性胆管癌の 1 例

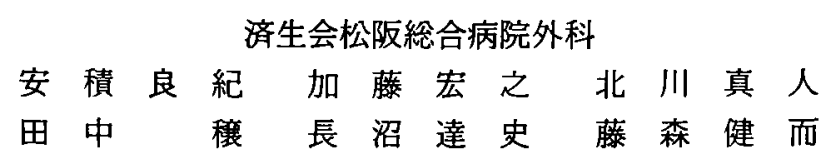

粘液産生性胆管癌は，多量の粘液を産生し，その多彩な症状，画像所見より確定診断 に難渋することも少なくない，今回は PTCS が診断・術式選択に有用であった粘液産生 性胆管癌の 1 切除例を経験したので報告する。症例は78歳, 女性, 2001年 4 月26日全身 僚急感, 食思不振, 発熱を主訴に当院受診. 血液検査にて軽度の炎症所見, 肝胆道系醉 素の上昇, CEA の軽度上昇を認めた. US, CT にて肝内胆管, 総胆管の著明な㹡張, ERCP にて肝内胆管, 総胆管内の透亮像, PTCSにて後区域枝から総胆管にかけて, 多量の粘 液および顆粒状病変を認めた。 以上より粘液産生性胆管癌を強く疑い, 2001年12月10日 肝後区域切除十肝外胆管切除, D2リンパ節部清術施行. 病理学的に papillomatosis を基 盤とした高分化型腺癌と診断された. 術後 3 年目の現在, 無再発生存中である.

卖引用語：粘液産生胆管癌, papillomatosis, PTCS

\section{緒 言}

粘液産生性胆管癌は, 多量の粘液を産生し肝内胆管 技の宾胞状㹡張や総胆管の拡張, 粘液による閉塞性黄 疸や胆管炎など独特の臨床像を呈する．その多彩な臨 床像，画像所見のため，確定診断に難啮することも少 なくない1).今回われわれは経皮経肝的胆道鏡 (PTCS) が進展範囲の診断および術式選択に有用であった粘液 産生性胆管癌の 1 切除例を経験したので報告する.

$$
\text { 症例 }
$$

患者：78歳，女性.

主訴：全身倦急感, 食思不振, 発熱.

既往歴: 55歳時, 胆基結石症にて胆衰摘出術.

現病歴：2001年 4 月 20 日加全身隐意感，食思不振， 発熱が出現し, 近医受䛦。血液検查にて肝機能異常を 指摘され，当院紹介受診，精査目的に 4 月 26 日入院と なった。

入院時現症 : 体温 $37.6^{\circ} \mathrm{C}$, 血圧 $124 / 68 \mathrm{mmHg}$, 結膜 に蔶血，黄疸は認めず。腹部は平坦軟，圧痛は認めず， 明らかな腫瘤も触知しなかった。

2005年 2 月 24 日受付 2005 年 4 月 6 日採用 〈所属施設住所〉

T515-8557 松阪市朝日町一区15-6
入院時検査所見：一般検血ではWBC $4,400 / \mu 1$ と 正常で, 筫血も認めなかった. 生化学検査は T-Bil 0.8 $\mathrm{mg} / \mathrm{dl}$, GOT 204IU/1, GPT 261IU/l, ALP 1,060IU/ $1, \gamma \mathrm{GTP} 854 \mathrm{IU} / 1$ と肝胆道系醉素の上昇, おょび CRP $2.1 \mathrm{mg} / \mathrm{l}$ と軽度の炎症所見を認めた. 腫瘍マーカーは CEA 2.9ng/ml と微增を認めた.CA19-9は正常範囲内 であった。

腹部超音波検査 (US) 所見：左右肝内胆管の应張 および総胆管径 $18 \mathrm{~mm}$ と著明な㹡張を認めた。

腹部 computed tomography (CT) 検查所見 : 左右 肝内胆管の抎張を認め, 総胆管は総胆管下部まで著明 に拡張を認めた。総胆管内腔は肝内胆管内腔と比し, density の上昇を認め, 総胆管結石が疑われた。肝実質 には異常は認めなかった（図 1 a , b).

内視鏡的逆行性膵胆管造影 (ERCP) 所見：十二指 腸乳頭部には異常を認めずまた粘液の流出も認めな かった．総胆管は $19 \mathrm{~mm}$ と拡張し, 内部に不定形の透 亮像を多数認めた（図 $1 \mathrm{c}$ ).

この後, 症状が改善したため一旦退院となるが, 患 者の自己判断にて通院しなかった。10月9日に全身倦 急感, 発熱などの症状の再燃を認めたため, 再入院と なった.

再入院時現症：体温 $38.1^{\circ} \mathrm{C}$, 血圧 $118 / 70 \mathrm{mmHg}$, 結 

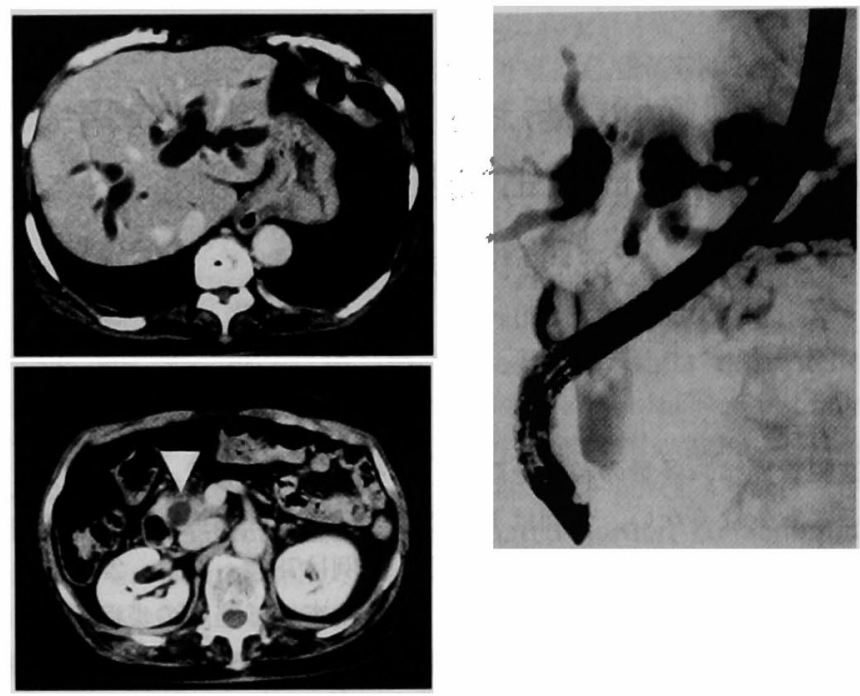

図 1 初回入院時画像所見：a）CTにて左右肝内胆管の著明な拡張 を認めた。 b ) 矢頭に示すごとく総胆管の著明な拡張を認めた，c） $\mathrm{ERCP}$ にて左右肝内胆管, 総胆管の著明な拡張および多数の透亮像 を認めた。
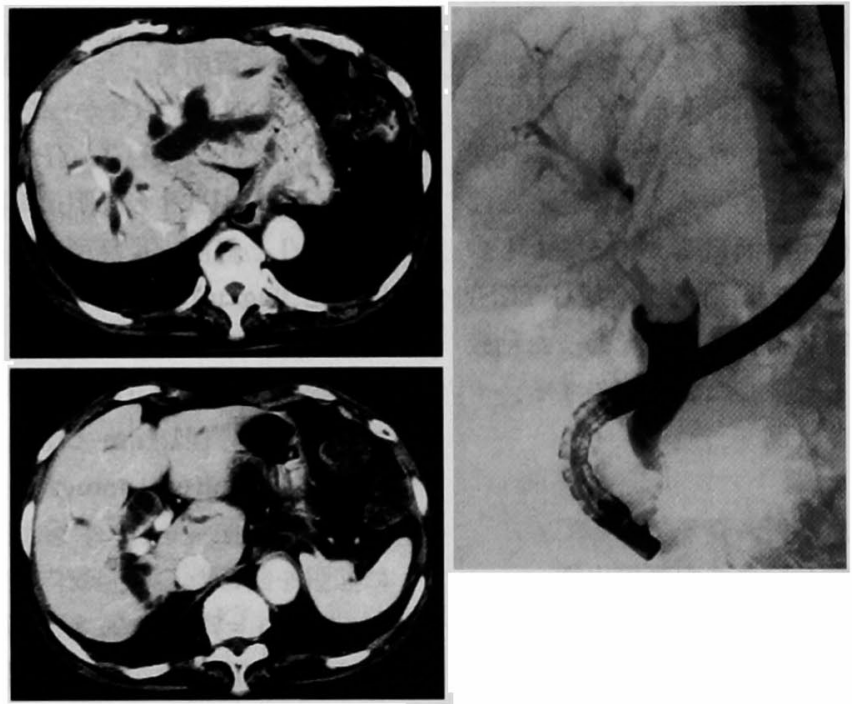

図 2 再入院時画像所見：a）CT にて前回同様著明な肝内胆管の拡 張を認めた. b ) 後区域は初回入院時と比し萎縮傾向を示している. c) 初回入院時と比較して透亮像上り頭側への造影剤の流入不良を 認めた.

膜に貧血，黄㾝は認めず。腹部は平坦軟，圧痛は認め ず.明らかな腫瘤も触知しなかった。

再入院時検査所見：一般検血では白血球 $4,600 / \mu 1$,
負血は認めなかった. 生化学検査では T-Bil 0.4mg/ dl, AST 20IU/1, ALT 24IU/1, ALP 557IU/1, $\gamma$ GTP $275 \mathrm{IU} / 1$ と胆道系酵素の上昇を認めた. CEA は $0.9 \mathrm{ng} /$ 
$\mathrm{ml}$ と正常化していた。

再入院時 CT 所見：前回入院時と同椂に左右肝内胆 管および総胆管の拡張を認めたが，初回入院時に認め た総胆管内腔の density の上昇は認めなかった，後区 域は初回入院時と比し萎縮傾向を認めた(図 $2 \mathbf{a}, \mathbf{b})$.

ERCP，経口胆道鏡所見：総胆管結石に上る胆管炎 が症状の原因と考え，ERCP を行ったところ，総胆管， 肝内胆管に透亮像を認め, 頭側への造影郕の流入不良 を認めたため (図 $2 \mathbf{c}$ ), 内視鏡的乳頭切開術 (EST) を施行したところ, 黄色粘液の流出を認めた。

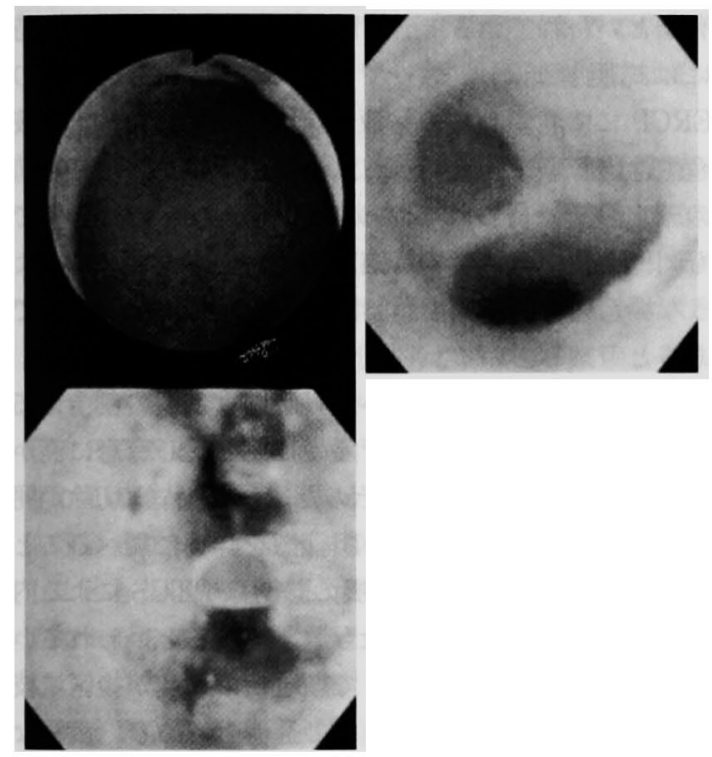

図 3 PTCS 所見：a）後区域枝には多量の粘液を認め た. b )後区域枝から右主肝管に広がる顆粒状の病変を 訆めた。（）左主肝管粘膜には異常は認めなかった。
PTCS 所見：拡張した B5より経皮経肝的胆道ドレ ナージ (PTCD) 施行後, PTCSを施行した. 前区域 枝, 左枝には異常を認めなかった，後区域枝には多量 の粘液を認め(図 $3 a$ ), 粘液を洗浄除去したところ後 区域枝から右主肝管に広がる顆粒状の病変を認めた

（図 3 b ) が, 左主肝管粘膜には異常は認めなかった (图 3 c).なお，後区域枝は門脈左枝前面で分岐する （いわゆる）南回りの形式で分岐していた。顆粒状病 変部の生検では adenocarcinoma が疑われたが, 粘液 の細胞診は Class 2であった.

腹部血管造影検査：肝後区域に血管增生を認め, 同 時に行った CT-HAでは後区域枝に2.5cm 大の類円 形の high density area として (図 4 a), CT-APて は low density area として描出され, 腫瘤もしくは炎 症性変化と考えられた（図 4 b). 明らかな肝転移は認 めなかった.

以上の所見より後区域枝原発の粘液産生性胆管癌を 疑い，2001年12月10日手術を施行した。

手術：両側季肋下切開にて開腹. 総胆管の拡張を認 めるも，明らかな腫㿔は触知されず，また肝後区域は 著明に萎縮していた，腹部血管造影にて高吸収域に描 出された部分には術中エコー上, 明らかな腫瘤性病変 は認めず, 炎症性変化と考えられた。腫瘍を一塊とし て切除するために, 肝後区域切除十肝外胆管切除, 2 群リンパ節郭清術を施行した.

摘出標本：腫晹の存在した後区域は強い萎縮を認 め, 後区域枝から肝外胆管にかけて粗造な粘膜を認め たが，明らかな腫㿔形成は誌めなかった。

病理所見：摘出標本のシェーマ(図 5 ) および病理 所見を示す. HE 染色で肝外胆管から後区域枝にかけ papillomatosis を認め(図6 a), 一部に well differ-
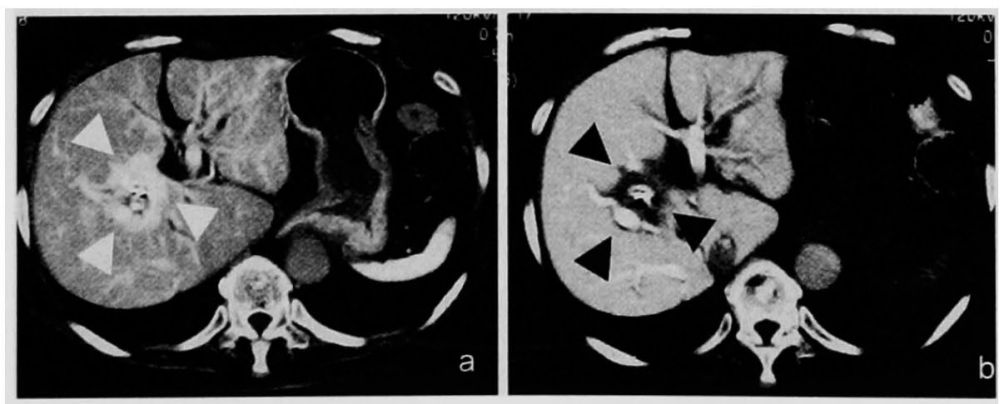

図 4 アンギオ CT 所見：a ) CT-HA, 後区域枝に $2.5 \mathrm{~cm}$ 大の類円形の高吸収域 を認める．b) CT-AP，同部位は低吸収域として描出された，以上より腫痦形 成もしくは炎症性変化が疑われた。 
entiated adenocarcinoma を認めた（図 6 b). 腫瘍進 展度は $\mathrm{m}, \mathrm{pHinf} 0, \mathrm{pGinf} 0, \mathrm{pPanc} 0, \mathrm{pDu} 0, \mathrm{pPV} 0$, $\mathrm{pA} 0, \mathrm{H} 0, \mathrm{P} 0, \mathrm{St}(-)$, pT1, pN0, M(-), fStage I であった. 以上より papillomatosis を基盤とし発生 した粘液産生性胆管癌と考えられた。

術後 3 年の現在も患者は健在であり, 無再発生存中 である。

\section{考察}

粘液産生性胆管癌は比較的稀な疾患で, その頻度は 全胆管癌の $4 \%$ 程度と報告されており ${ }^{2)}$, 梛野ら ${ }^{11} は{ }^{5}$ 床レベルにおいても認識しうるほどの多量の粘液を産 生する胆管癌を粘液産生性胆管癌と定義している.

その病因として, Chou ら ${ }^{3)}$ は剖検例50例の検討によ り, $92 \%$ に肝吸虫症の合併を認めることから, 肝吸虫 の機械的刺激により癌化するのではないかと推測して おりまた Helpap ${ }^{4}$ は胆管に papillomatosis を伴った 12例を検討し, papillomatosisに慢性炎症を繰り返し， hyperplasia, goblet-cell metaplasiaを発生し粘液産生 性胆管癌に変化していくのではないかと考察している.

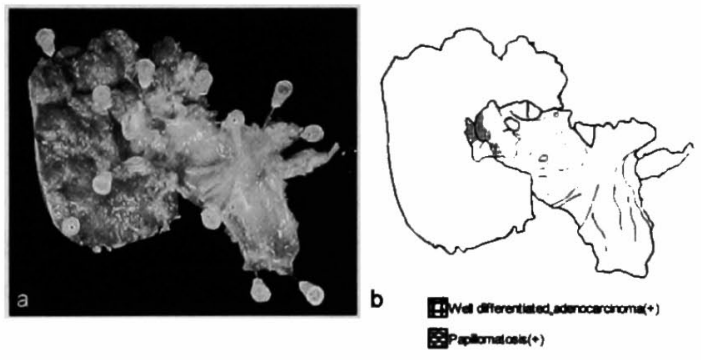

図 $5 a$ 摘出標本所見， bシェーマ：シェーマに示す範 囲で粘膜変化を認め，網掛け部より高分化型腺癌が認 められた。
自験例では臨床的に胆管内に多量の粘液貯留を認め たことより，梛野らの粘液産生性胆管癌の定義にあて はまると思われる。また肝吸虫症の所見は認めず，総 胆管側の病変には papillomatosis を認め,その一部に 高分化型腺癌を認めることより, Helpap らの機序に よって発生したものと推測される.

術前診断において総胆管結石や肝内結石と診断して いる報告が散見され，確定診断に難渋することも少な くない. 粘液産生性胆管癌の確定診断を得るためには, 一般に ERCP による乳頭の拡張, 粘液の流出の確認, $\mathrm{PTCD}$ による選択的造影, PTCSによる直視下生検が 有効といわれている(1). 自験例においても初回入院時 には総胆管結石を疑っていたが，二回目入院時の ERCP にて乳頭からの粘液の流出を認めたため，粘液 産生性胆管癌を強く疑った。自験例では生検にて術前 の確定診断は得られなかったが，鬼頭ら の報告例て も同様に生検の結果では確定診断が得られず，このよ うな場合には胆道内視鏡診断を優先して対処すべきで あると考察している。

粘液産生性胆管癌において表層拡大進展の割合は45 \%に認められ，通常型胆管癌の $15 \%$ と比し有意に高加 ったと報告されている の選択においては, 術前の胆管像を詳細に調べること が重要であり, 表層拡大進展の診断は PTCSによる内 視鏡所見と直視下生検が最も重要であるといわれてい $3^{778)}$. 自験例でも PTCSにて顆粒状の病変が後区域枝 から左右肝管合流部付近にまで進展しており，広範な 表層拡大進展が疑われたため, 肝外胆管切除を併施し た. 病理所見でこれらの病変は papillomatosis が広範 井に存在し，この一部に高分化型腺癌を認めた。

粘液産生性胆管癌の切除後生存率をみると, 切除に

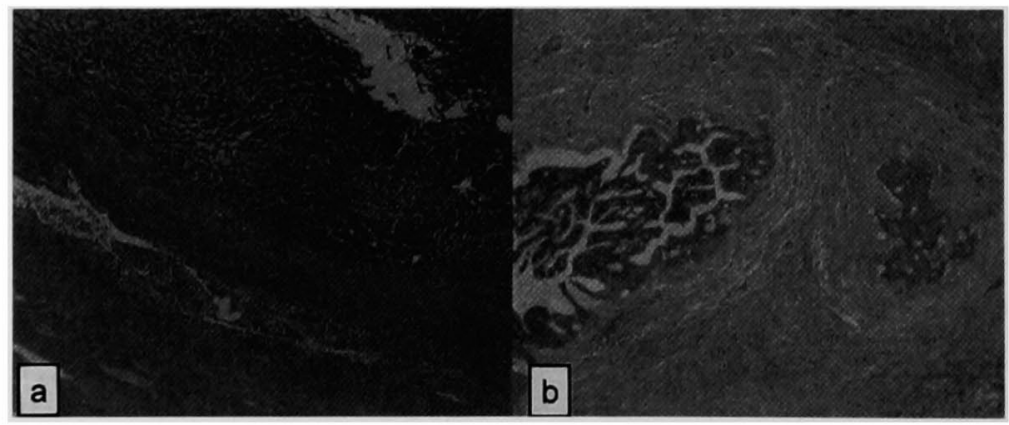

図 6 病理組織学的所見：a）炎症所見を認め papillomatosis と診断された（H. E.染色 $\times 40)$. b ) Papillomatosis $の 一$ 部に腺管拡張, 乳頭状増生を認め高分化 型腺癌と診断された（H.E.染色×100）. 
至るまでの病悩期間が平均30力月と長期であるにもか かわらず, 通常型胆管癌と比し, 長期予後成績がよ く ${ }^{9)}$, 坂本ら ${ }^{61}$ 報告では50\%生存期間は通常型胆管 瘦：粘液産生性胆管癌 $=2.1$ 年: 10.8 年と粘液産生性 胆管癌は有意に予後良好であった。これは粘液の貯留 による胆管炎や黄㾝などにより早期に発見されること が多いことや，粘液産生性胆管癌自体が low grade malignancy, slow growing な性格であることに起因 すると考えられる。また死亡例は切除例では高度浸潤 癌によるものが多く, 非切除例では腫瘍浸潤よりも粘 夜による閉塞性黄㡺や胆管炎により死亡する場合が多 いとされている6). 近年では全身状態不良例でのマイ クロ波凝固療法 ${ }^{10}$ やレーザー治療 ${ }^{11}$ も報告されてい る.

粘液産生性胆管癌症例の粘液中には癌細胞が浮遊し ていることが多く, 術前検查時の腹腔内散布による再 発例や，PTCDの瘦孔からの再発例も報告されてお り, 術前検査時の対処や手術時の㿉孔の処置などに敨 重な注意が必要であると述べられている5!。

自験例でも病悩期間が 8 力月と比較的長かったが, 術前 PTCSにて癌の基盤となった papillomatosisを 含めての進展範囲の把握が可能であり，根治的切除を 施行しえた。 また後区域枝が，いわゆる南回りであっ たことも後区域切除十肝外胆管切除にて en blockに 切除するのに有利な材料となったと思われる.

$$
\text { 結語 }
$$

術前PTCS が進展範囲診断および術式選択に有用 であった粘液産生性胆管癌の 1 例を経験した。

$$
\text { 文献 }
$$

1）梛野正人, 二村雄次, 早川直和他：粘液産生胆管 癌の臨床病理学的研究.日外会誌 91:695-704, 1990
2) Henson DE, Albores Saavedra J, Corle D: Carcinoma of the extrahepatic bile ducts. Histologic types, stage of disease, grade and survival rates. Cancer $70: 1498-1501,1992$

3) Chou ST, Chan CW : Mucin-producing cholangiocarcinoma : an autopsy study in Hong Kong. Pathology 8:321-328, 1976

4) Helpap B:Malignant papillomatosis of the intrahepatic bile ducts. Acta Hepato-Gastroenterol $24: 419-425,1977$

5）鬼頭 清, 神谷順一, 梛野正人他：胆管拡張の経 過観察中に診断された粘液産生肝内胆管癌の 1 例. 消画像 1：263-268, 1999

6）坂本英至, 神谷順一, 近藤哲他：知っておくへ き疾患一胆・膵粘液産生胆管癌。臨消内科 13 ： $1611-161 \%, 1998$

7) 二村雄次, 神谷順一, 早川直和他：PTCSによる 表層扩大型胆管癌の診断.腹部画像診断 $6: 333$ $-345,1986$

8）神谷順一, 二村雄次, 早川直和他：PTCD 造影お よび PTCSによる肝門部胆管癌の進展度診断. 腹 部画像診断 $9: 545-551,1989$

9）永川裕一, 青木達哉, 土田明彦他：総胆管結石と 見誤られた粘液産生胆管癌の 1 例.胆道 $11: 302$ $-306,1997$

10）白川京佐，渡莩文利，丸山保彦他：粘液産生胆管 瘟に対してマイクロ波凝固療法が有効であった 1 例。日消内視鏡会誌 45:2118-2123，2003

11）豊川達也, 池田宣聖, 水野元夫他: 遅発成長を示 す粘液産生胆管癌に対してレーザー治療を試みた 1 例. Gastroenterol Endosc 39:825-830, 1997 


\title{
A CASE OF MUCUS PRODUCING CHOLANGIOCARCINOMA IN WHICH PTCS WAS USEFUL FOR DIAGNOSING THE EXTENTION OF INVASION AND CHOOSING THE MODALITY OF SURGICAL TREATMENT
}

\author{
Yoshinori AZUMI, Hiroyuki KATO, Masato KITAGAWA, \\ Minoru TANAKA, Tatsushi NAGANUMA and Kenji FUJIMORI \\ Department of Surgery, Saiseikai Matsusaka General Hospital
}

Mucus producing cholangiocarcinoma secrets large amount of mucus and is often difficult to make diagnosis accompanied with varieties of symptoms and pictures in image studies. We report a case of mucus producing cholangiocarcinoma in which PTCS was useful in making diagnosis and selecting the choice of surgical treatment. The patient was 78-year-old female who presented to us with general malaise, anorexia and fever. The blood test revealed the presence of mild inflammation, mild elevation of hepatic enzymes and CEA. The intrahepatic and common bile ducts revealed significant dilatation in US and CT studies and abnormal images in ERCP. The study with PTCS revealed mucoid and granular disease in the intrahepatic ducts of posterior segment and common bile duct. Accordingly, the diagnosis of mucus producing cholangiocarcinoma was strongly suspected and resection of posterior hepatic segment, extrahepatic bile duct and removal of D2 lymphnodes were performed on Dec. $10^{\text {th }}, 2001$. The pathological diagnosis was well differentiated adenocarcinoma arising in papillomatosis. The patient is surviving without sign of recurrence three years after the operation. 